\title{
Biochemical composition of Microcystis aeruginosa related to specific growth rate: insight into the effects of abiotic factors
}

Ming Li ${ }^{1,2, *}$, Philip Nti Nkrumah ${ }^{2}$, Man Xiao $^{2}$

${ }^{1}$ College of Resources and Environment, Northwest A \& F University, Yangling 712100, PR China

${ }^{2}$ College of Environment, Hohai University, No. 1 Xikang Road, Nanjing 210098, PR China

*Corresponding author; E-mail: lileaf@163.com 
Abstract: The content of different Microcystis biochemical components (including total polysaccharides (TPS), proteins and RNA) were analyzed at different growth rates obtained under varying light intensities, temperatures and nutrient concentrations. Higher light intensity and temperature yielded a higher specific growth rate of Microcystis but the two different culture media did not significantly affect growth of Microcystis in the current study. The differences in the cellular content of TPS, protein and RNA at different temperatures $\left(20\right.$ and $\left.25^{\circ} \mathrm{C}\right)$ were significant under both light intensities. The differences under different light intensities (30 and $60 \mu \mathrm{mol}$ photons $\mathrm{m}^{-2} \mathrm{~s}^{-1}$ ) were significant at $25^{\circ} \mathrm{C}$ but negligible when temperature was $20^{\circ} \mathrm{C}$. These phenomena suggested that temperature would be the limiting factor influencing the cellular processes when temperature was $20^{\circ} \mathrm{C}$. However, when temperature was $25^{\circ} \mathrm{C}$, the limiting factor was observed to be light intensity. The results also demonstrated that the content of TPS and RNA decreased, but the value of proteins increased with an increase in specific growth rate.

Keywords: Microcystis aeruginosa, specific growth rate, polysaccharide, carbohydrate transformation 


\section{Introduction}

Colony formation is an important contributor to the dominance and bloom formation of the harmful cyanobacterium Microcystis in lakes and reservoirs (Yamamoto et al., 2011). This is because of its advantages in anti-predator defense (Cyr and Curtis, 1999) and high floating velocities (Wu and Kong, 2009). Extracellular polysaccharides (EPSs) were reported to play an important role in Microcystis colony formation (Plude et al., 1991). The increase of EPS content could promote colony formation in Microcystis (Yang et al., 2008). EPS is secreted by Microcystis cells and derived from intracellular polysaccharide (IPS). Moreover, the EPS content has been reported to be closely related to the IPS content (Yang et al., 2008). It must be noted that the combination of EPS and IPS is the total polysaccharide content (TPS).

Carbohydrates, the photosynthetic products of Microcystis, would transform into polysaccharides (same as TPS), proteins, and nucleic acids (mainly be RNA), if they are not used in respiration. Rapid synthesis of protein and RNA would cause the synthetic rate of TPS decrease (Dai et al. 2013). Thus, study on the proportions of different biochemical components in Microcystis (including TPS, proteins and RNA) with varying abiotic factors can provide deeper insight into changes in cellular TPS content and colony formation of Microcystis.

The synthetic processes of TPS, protein and RNA are affected by abiotic factors such as light intensity, temperature and nutrient (especially nitrogen), which in turn affect the growth rate of Microcystis. It has been reported that TPS is negatively correlated with the specific growth rate of Microcystis cultured at different light intensity and phosphorus concentration (Wang et al., 2010). Our previous work (Li et al., 2013) also demonstrated a negative correlation between the specific growth rate and cellular polysaccharide content (EPS and IPS) in Microcystis with varying light intensity and temperature. Some researchers (Long et al., 2001; Oh et al., 2000) have found that the proportions of protein are different at different specific growth rates. It is important to note that the content of protein and RNA may be higher at a higher specific growth rate with high light intensity and temperature because protein and RNA relate 
significantly to cell division (Rhee 1978). Thus, we hypothesized that the content of TPS, protein and RNA relate significantly to specific growth rate under different abiotic conditions.

The aim of this study was to ascertain the effects of light intensity, temperature and nutrient concentration on the biochemical components of Microcystis. Specifically, Microcystis biochemical components were analyzed to elucidate the variations in proportions of different Microcystis biochemical components.

\section{Materials and Methods}

Organisms: Microcystis aeruginosa (Kützing) Kützing 1846 strain (FACHB 469) was obtained from the Freshwater Alga Culture Collection of the Institute of Hydrobiology, Chinese Academy of Sciences. This unicellular strain was subjected to long-term axenic cultivation in BG-11 medium. Algae, cultured for seven days (late exponential growth phase), were used in our experiments.

Cultivation and adjustment of specific growth rate: The algae were batch-cultured in triplicate under eight different light intensities $(25,30,35,40,45,50,55$, and 60 $\mu \mathrm{mol}$ photons $\left.\mathrm{m}^{-2} \mathrm{~s}^{-1}\right)$ at $20^{\circ} \mathrm{C}$ and $25^{\circ} \mathrm{C}$ in BG-11 medium and $\mathrm{M}-11$ medium (150 $\mathrm{mL}$ medium in a $250 \mathrm{~mL}$ conical flask) under a 12:12 hour light-dark cycle, respectively. Two media were used to make sure nutrient concentration would not affect the relationship between biochemical composition and the specific growth rate of Microcystis. The initial $\mathrm{pH}$ of each medium was adjusted to 8.0 using a $5 \mu \mathrm{M}$ $\mathrm{NaOH}$ solution. The initial cell density of $M$. aeruginosa was $5 \times 10^{4}$ cells $\mathrm{mL}^{-1}$. Flasks were shaken by hand, two to three times daily, to prevent cells from adhering to the inner walls of flasks.

Cell counting and specific growth rate calculation: The culture time was nine days for all cultures and the specific growth rate was determined on day nine by cell counting. To dissociate the colonies into single cells, a centrifuge tube containing 3 $\mathrm{mL}$ culture sample was placed in a $100^{\circ} \mathrm{C}$ water-bath oscillator and shaken at $120 \mathrm{rpm}$ for $5 \mathrm{~min}$. The cells were counted three times in a haemocytometer under an optical 
microscope (Olympus CX31, Olympus Corporation) at $400 \times$ magnification. If the three counts differed by less than $10 \%$, the average count was designated the final cell density. Otherwise, additional counting was carried out (Li et al., 2013).

The specific growth rate $(\mu)$ was calculated from the following equation (1):

$$
\mu=\ln \left(\mathrm{D}_{\mathrm{t}} / \mathrm{D}_{0}\right) / \mathrm{t}
$$

where $D_{t}$ is the cell density at time $t, D_{0}$ is the initial cell density, and $t$ is the period of the logarithmic growth phase, which is nine in the current study.

Chemical analysis: The cultured samples $(20 \mathrm{~mL})$ were filtered through a tared $\mathrm{GF} / \mathrm{C}$ glass-fiber filter (Whatman, Maidstone, UK), and then dried using a vacuum freeze dryer for $24 \mathrm{~h}$ to gain the dry weight. The content of carbon and nitrogen was analyzed via a Vario EL- III element analyzer. The cultured samples $(20 \mathrm{~mL})$ were centrifuged at 11,550 $\mathrm{g}$ for $15 \mathrm{~min}$, and the supernatants were discarded. The pellets were re-suspended in their centrifuge tubes in $5 \mathrm{~mL}$ of $0.5 \mathrm{~mol} \mathrm{~L}^{-1}$ caustic soda solution (Rausch, 1981). The tubes were placed in a $100^{\circ} \mathrm{C}$ water-bath oscillator, shaken at $120 \mathrm{rpm}$ for $15 \mathrm{~min}$, and then centrifuged at $11,550 \mathrm{~g}$ for $15 \mathrm{~min}$. Supernatants were then separated from pellets. Two repeats of these procedures were carried out. Supernatants were combined, and the polysaccharide content and protein content of the combined supernatants were assayed using the anthrone sulfuric acid method and Coomassie Brilliant Blue method, each in triplicate, and normalized by cell counts.

For RNA content analysis, cultured samples $(20 \mathrm{~mL})$ were centrifuged at $11,550 \mathrm{~g}$ for $15 \mathrm{~min}$, and the supernatants were discarded. The pellets were re-suspended in $50 \mathrm{~mL}$ centrifuge tubes containing $5 \mathrm{~mL}$ of $1 \mathrm{~mol} \mathrm{~L}^{-1} \mathrm{HClO}_{3}$, placed in a $90^{\circ} \mathrm{C}$ water-bath oscillator, shaken at $120 \mathrm{rpm}$ for $15 \mathrm{~min}$, and then centrifuged at 11,550 g for $15 \mathrm{~min}$. Supernatants were then separated from pellets. Two repeats of these procedures were carried out. Supernatants were combined and the content of RNA was analyzed following the methods described by Rhee et al. (1978).

Statistical analysis: The specific growth rate was presented as mean $\pm \mathrm{SD}$. Other data were presented as mean and a Pearson correlation was used to analyze their relations 
to specific growth rate. The differences of dry weight, contents of TPS, protein and RNA were analyzed by one-way ANOVA using tukey post hoc test. All statistical analyses were performed using SPSS 10.0.

\section{Results}

\section{Growth of $M$. aeruginosa under different culture conditions}

Figure 1 shows the specific growth of $M$. aeruginosa under varying light intensities at $20^{\circ} \mathrm{C}$ and $25^{\circ} \mathrm{C}$ in BG-11 and M-11 media, respectively. The specific growth rate of $M$. aeruginosa was obviously affected by light intensity and temperature but no significant differences were found between the two different culture media. The maximum specific growth rate, obtained under a light intensity of $60 \mu \mathrm{mol}$ photons $\mathrm{m}^{-2} \mathrm{~s}^{-1}$ was 0.62 day $^{-1}$ and $0.55 \mathrm{day}^{-1}$ at $25^{\circ} \mathrm{C}$ and $20^{\circ} \mathrm{C}$, respectively. The minimum specific growth rate was 0.55 day $^{-1}$ and 0.32 day $^{-1}$ at $25^{\circ} \mathrm{C}$ and $20^{\circ} \mathrm{C}$, respectively.

[Insert Fig. 1 here]

The variation in cellular dry weight of $M$. aeruginosa along with the increase in specific growth rate, is shown in Fig. 2. The cellular dry weight was $17-23$ pg cell $^{-1}$ and decreased slightly with increasing specific growth rate.

\section{Variation of biochemical composition}

Figure 3 shows the relationship between specific growth rate and Microcystis biochemical components. Cellular TPS and RNA decreased with increasing specific growth rate. The cellular TPS content at a specific growth rate of 0.40 day $^{-1}$ was approximately three times greater than the content at a specific growth rate of 0.60 day $^{-1}$. However, a significant positive linear relationship was found between cellular protein content and specific growth rate. Cellular protein content increased from 6 to $8 \mathrm{pg} \mathrm{cell}^{-1}$ while specific growth rate increased from 0.4 to $0.6 \mathrm{day}^{-1}$.

[Insert Fig. 3 here]

\section{Content of carbon and nitrogen}

Figure 4 shows carbon and nitrogen content of Microcystis at different specific growth rate under different culture conditions. Both carbon and nitrogen content increased 
with increasing specific growth rate. The carbon content and nitrogen content increased from $22 \%$ to $28 \%$ and from $4 \%$ to $5 \%$, respectively, while the specific growth rate of 0.40 day $^{-1}$ increased from 0.4 to 0.6 day $^{-1}$.

[Insert Fig. 4 here]

\section{Differences of biochemical components under different conditions}

Figure 5 illustrates the differences of Microcystis biochemical components under different conditions. No significant differences were found in the dry weight under different culture conditions. Under the light intensity of $30 \mu \mathrm{mol}$ photons $\mathrm{m}^{-2} \mathrm{~s}^{-1}$, the cellular TPS content at $20^{\circ} \mathrm{C}$ was significantly higher than that at $25^{\circ} \mathrm{C}$ but the relation was inverse under the light intensity of $60 \mu \mathrm{mol}$ photons $\mathrm{m}^{-2} \mathrm{~s}^{-1}$. This change pattern of TPS was similar to that of RNA but opposite to that of protein. The differences in the cellular content of TPS, protein and RNA between different light intensity (20 and $60 \mu \mathrm{mol}$ photons $\mathrm{m}^{-2} \mathrm{~s}^{-1}$ ) at $20^{\circ} \mathrm{C}$ were significant as well.

[Insert Fig. 5 here]

\section{Discussion}

It was expected that the cellular TPS content would be higher at higher specific growth rates than that at lower specific growth rate (Li et al. 2013) because the ability of Microcystis to produce carbohydrate was higher at higher temperature and light intensity. This assertion was denied by our current results. Although the ability of Microcystis to produce carbohydrate was promoted, the cellular TPS content was affected by the process of carbohydrate transformation.

We found that the percentage composition of TPS decreased from 10 to $5 \%$, but protein increased from 30 to $45 \%$ with an increase in specific growth rate from 0.3 to 0.6 day $^{-1}$ (data not shown). The percentage composition of RNA also decreased with increasing specific growth rate. Recently, Gan et al. (2012) reported that the regulation of certain parts of four polysaccharide biosynthesis-related genes would affect the polysaccharide content of Microcystis. Light conditions have also been reported to alter genetic expression in Microcystis (Straub et al., 2011). Changes in genetic expression may induce variation in the percentage composition of different 
Microcystis biochemical components.

Long et al. (2001) found that both the Microcystis cellular protein content and the percentage composition of protein were high at a higher specific growth rate under nitrogen-limited conditions, and vice versa. The same phenomenon has been reported by others (Downing et al., 2005; Wiedner et al., 2003). Oh et al. (2000) measured the specific growth rate, protein content (the ratio to dry weight of cells), and microcystin content of M. aeruginosa grown in P-limited medium modified from Smith and Wiedeman (1964). A correlation analysis of their data was performed and a significantly positive relationship between specific growth rate and percentage composition of protein $\left(r^{2}=0.760, n=8, P<0.01\right)$ was observed.

These findings have revealed that proportions of different Microcystis biochemical components vary along with changes in specific growth rate. Specifically, the proportions of TPS and nucleic acids transformed from carbohydrates decreased at a high specific growth rate but the proportions of protein increased. This process could be termed as a transformation effect, and may be the result of changes in genetic expression triggered by variation in environmental factors.

Protein is the main material of Microcystis cell construction and is closely related to the life activities of the cells. It is noteworthy that the correct proteins must be formed before cell division (Reynolds, 2006). Thus, high proportions of protein at high specific growth rates favor the maintenance of high specific growth rates in Microcystis. It was surprising that RNA content decreased along with the increase of growth rate of Microcystis. However, the reduction was observed to be slow and the RNA content was found to reduce from $20 \%$ to $10 \%$. Although, Nagai et al. (2011) established a positive relationship between RNA content and specific growth rate of Microcystis which was opposite to the relationship in the current study, it is worth noting that that positive relationship was only significant when the specific growth rate was below 0.2 day $^{-1}$. In addition, a decreasing trend of RNA content could be found when the specific growth rate was above 0.2 day $^{-1}$. In the current study, all the values of specific growth rate was larger than $0.3 \mathrm{day}^{-1}$. Thus, the relationship in previous study (Nagai et al. 2011) and the current study did not conflict to each other. 
The mechanisms of the interaction between specific growth rate and RNA content was unclear but the fact that a certain amount of RNA was a requirement for cell division was credible. Thus, the relationship between RNA content and specific growth rate and the underlying mechanism should be deliberated with more data.

Our results also illustrated that both carbon and nitrogen content increased along with the increase of growth rate of Microcystis with varying abiotic factors. The increasing carbon content indicated that the ability of carbohydrate synthesis was promoted at high growth rate resulting from high light intensity and temperature. However, Microcystis absorbed more nitrogen at higher specific growth rate to synthesize more protein to maintain the high rate of cell division. Thus, the TPS content decreased with the increase of specific growth rate.

In the current study, the selection of different growth medium neither provided different growth rates nor gave rise to differences in the cellular content of TPS, protein and RNA. Thus, nutrient content was high enough that it did not influence the growth and cellular processes.

The differences in the cellular content of TPS, protein and RNA at different temperatures $\left(20\right.$ and $\left.25^{\circ} \mathrm{C}\right)$ were significant under both light intensities. The differences under different light intensity (30 and $60 \mu \mathrm{mol}$ photons $\mathrm{m}^{-2} \mathrm{~s}^{-1}$ ) were significant at $25^{\circ} \mathrm{C}$ but negligible when temperature was $20^{\circ} \mathrm{C}$. These phenomena suggest that temperature was probably the limiting factor influencing the rates of cellular processes when temperature was $20^{\circ} \mathrm{C}$. However, when temperature was $25^{\circ} \mathrm{C}$, the limiting factor was observed to be light intensity. Robarts and Zohary (1987) suggested the optimal temperature for Microcystis growth was $25^{\circ} \mathrm{C}$ (or greater) and this support the assertion that the growth of Microcystis would not be limited by temperature. Yang et al. (2012) studied the combined effect of various environmental factors on the growth and TPS content of Microcystis. They reported that temperature had no effect on TPS content at both 25 and $30^{\circ} \mathrm{C}$. This finding supports our deduction that the limiting factor influencing the rates of cellular processes was not temperature but light intensity when temperature was $25^{\circ} \mathrm{C}$.

In conclusion, higher light intensity and temperature yielded a higher specific growth 
rate of Microcystis but the two different culture media did not significantly affect growth of Microcystis in the current study. The content of TPS and RNA decreased, but proteins increased with an increase in specific growth rate. Our results also suggested that temperature would be the limiting factor influencing the synthetic processes of TPS, protein and RNA when temperature was $20^{\circ} \mathrm{C}$. However, when temperature was $25^{\circ} \mathrm{C}$, the limiting factor was observed to be light intensity.

Acknowledgments: This study was sponsored by the National Program on Key Basic Research Project of China (2012CB719804), the Natural Science Foundation of Jiangsu Province (BK2011025), and the Hydraulic Science \& Technology Project of Jiangsu Province (2012012).

\section{References}

Cao H, Yang Z. 2010. Variation in colony size of Microcystis aeruginosa in a eutrophic lake during recruitment and bloom formation. J Freshwater Ecol 25: 331-335

Cyr H, Curtis JM. 1999. Zooplankton community size structure and taxonomic composition affects size-selective grazing in natural communities. Oecologia 118: 306-315

Dai X, Zhu W, Li M. 2013. Effects of nutrients on components and polysaccharide content of Microcystis cells. J Lake Sci 25: 277-282 (in Chinese with English abstract)

Downing TG, Sember CS, Gehringer MM, Leukes W. 2005. Medium N: P ratios and specific growth rate comodulate Microcystin and protein content in Microcystis aeruginosa PCC7806 and M. aeruginosa UV027. Microb Ecol 49: 468-473

Gan N, Xiao Y, Zhu L, Wu Z, Liu J, Hu C, Song L. 2012. The role of microcystins in maintaining colonies of bloom - forming Microcystis spp. Environ Microbiol 14: $730-742$

Kessel M, Eloff JN. 1975. The ultrastructure and development of the colonial sheath of Microcystis marginata. Arch Microbiol 106: 209-214

Li M, Zhu W, Gao L, Lu L. 2013. Changes in extracellular polysaccharide content and morphology of Microcystis aeruginosa at different specific growth rates. J Appl 
Phycol 25: 1023-1030

Long BM, Jones GJ, Orr PT. 2001. Cellular microcystin content in N-limited Microcystis aeruginosa can be predicted from growth rate. Appl Environ Microb 67: 278-283

Oh HM, Lee SJ, Jang MH, Yoon BD. 2000. Microcystin production by Microcystis aeruginosa in a phosphorus-limited chemostat. Appl Environ Microb 66: 176-179 Plude JL, Parker DL, Schommer OJ, Timmerman RJ, Hagstrom SA, Joers JM, Hnasko R. 1991. Chemical characterization of polysaccharide from the slime layer of the cyanobacterium Microcystis flos-aquae C3-40. Appl Environ Microb 57: 1696-1700

Rausch T. 1981. The estimation of micro-algal protein content and its meaning to the evaluation of algal biomass I. Comparison of methods for extracting protein. Hydrobiologia 78: 237-251

Reynolds CS. 2006. Growth and replication of phytoplankton. in The ecology of phytoplankton. Cambridge University Press, New York: 179-180

Rhee GY. 1978. Effects of N: P atomic ratios and nitrate limitation on algal growth, cell composition, and nitrate uptake. Limnol Oceanogr 23: 10-25

Robarts RD, Zohary T. 1987. Temperature effects on photosynthetic capacity, respiration, and growth rates of bloom-forming cyanobacteria. New Zeal J Mar Fresh 21: 391-399

Smith RL, Wiedeman VE. 1964. A new alkaline growth medium for algae. Can J Bot 42: $1582-1586$

Straub C, Quillardet P, Vergalli J, de Marsac NT, Humbert JF. 2011. A day in the life of Microcystis aeruginosa strain PCC 7806 as revealed by a transcriptomic analysis. PLoS One 6: e16208. doi:10.1371/journal.pone.0016208

Wang C, Kong H, He S, Zheng X, Li C. 2010. The inverse correlation between growth rate and cell carbohydrate content of Microcystis aeruginosa. J Appl Phycol 22:105-107

Wiedner C, Visser PM, Fastner J, Metcalf JS, Codd GA, Mur LR. 2003. Effects of light on the microcystin content of Microcystis strain PCC 7806. Appl Environ 
Microb 69: 1475-1481

Wu X, Kong F. 2009. Effects of light and wind speed on the vertical distribution of Microcystis aeruginosa colonies of different sizes during a summer bloom. Int Rev Hydrobiol 94: 258-266

Yamamoto Y, Shiah FK, Chen TL. 2011. Importance of large colony formation in bloom-forming cyanobacteria to dominate in eutrophic ponds. Ann Limnol - Int J Lim 47: $167-173$

Yang Z, Kong F, Shi X, Zhang M, Xing P, Cao H. 2008. Changes in the morphology and polysaccharide content of Microcystis aeruginosa (Cyanobacteria) during flagellate grazing. J Phycol 44: 716-720

Yang Z, Geng L, Wang W, Zhang J. 2012. Combined effects of temperature, light intensity, and nitrogen concentration on the growth and polysaccharide content of Microcystis aeruginosa in batch culture. Biochem Syst Ecol 41: 130-135

\section{Figure captions:}

Fig. 1 The specific growth of $M$. aeruginosa under varying light intensities at $20^{\circ} \mathrm{C}$ and $25^{\circ} \mathrm{C}$ in BG-11 medium and M-11 medium, respectively.

Fig. 2 Variation in cellular dry weight of M. aeruginosa along with increase in specific growth rate.

Fig. 3 Relationship between specific growth rate and percentage composition of Microcystis biochemical components.

Fig. 4 Carbon and nitrogen content of Microcystis at different specific growth rate under different culture conditions.

Fig. 5 The differences of Microcystis biochemical components under different conditions.

+ Indicates that differences of Microcystis biochemical components between different temperatures or different medium under the same light intensity are significant $(\mathrm{P}<0.05)$

* Indicates that differences of Microcystis biochemical components between different light intensities at the same temperature with the same medium are 
significant $(\mathrm{P}<0.05)$

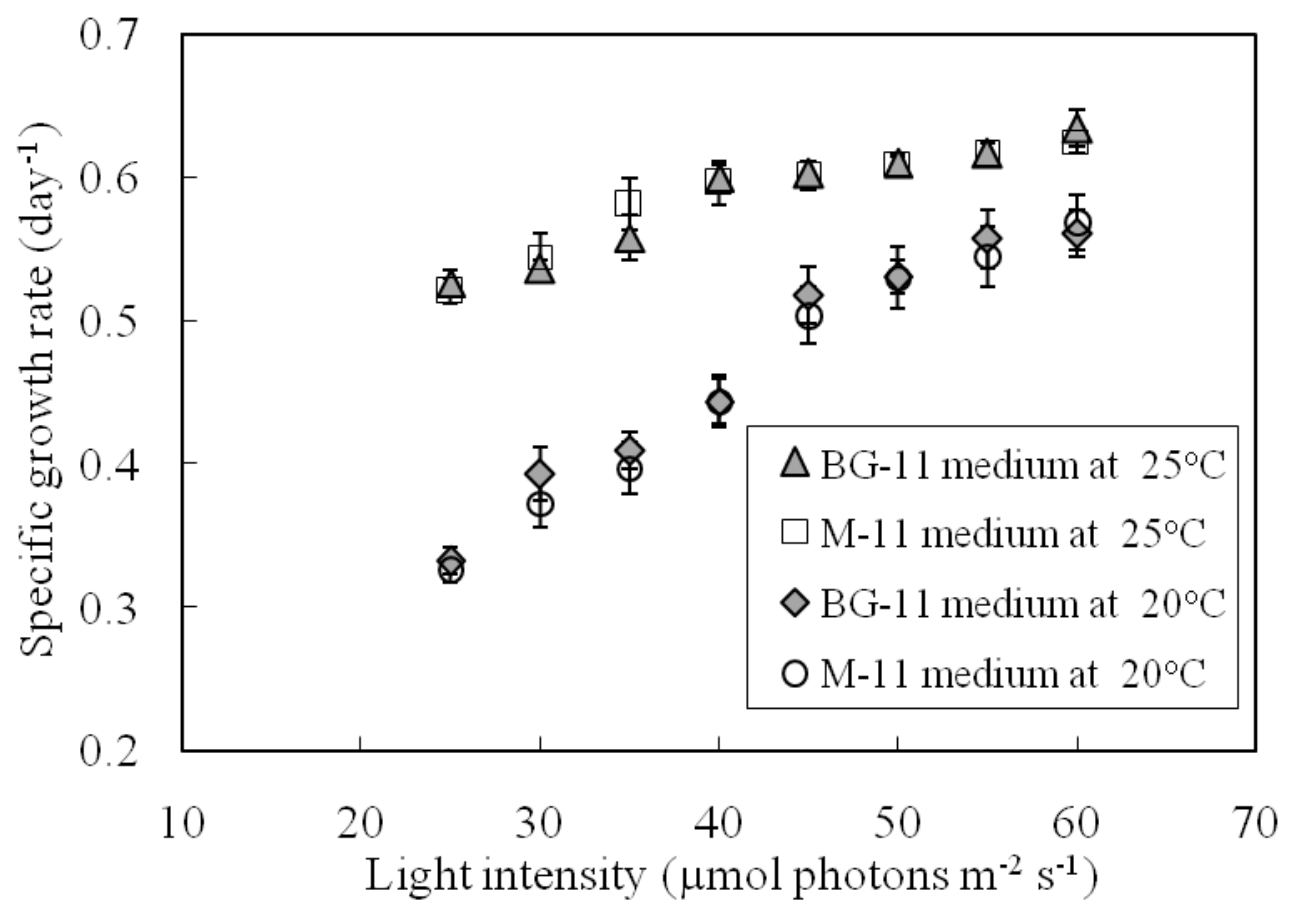

[Fig. 1]

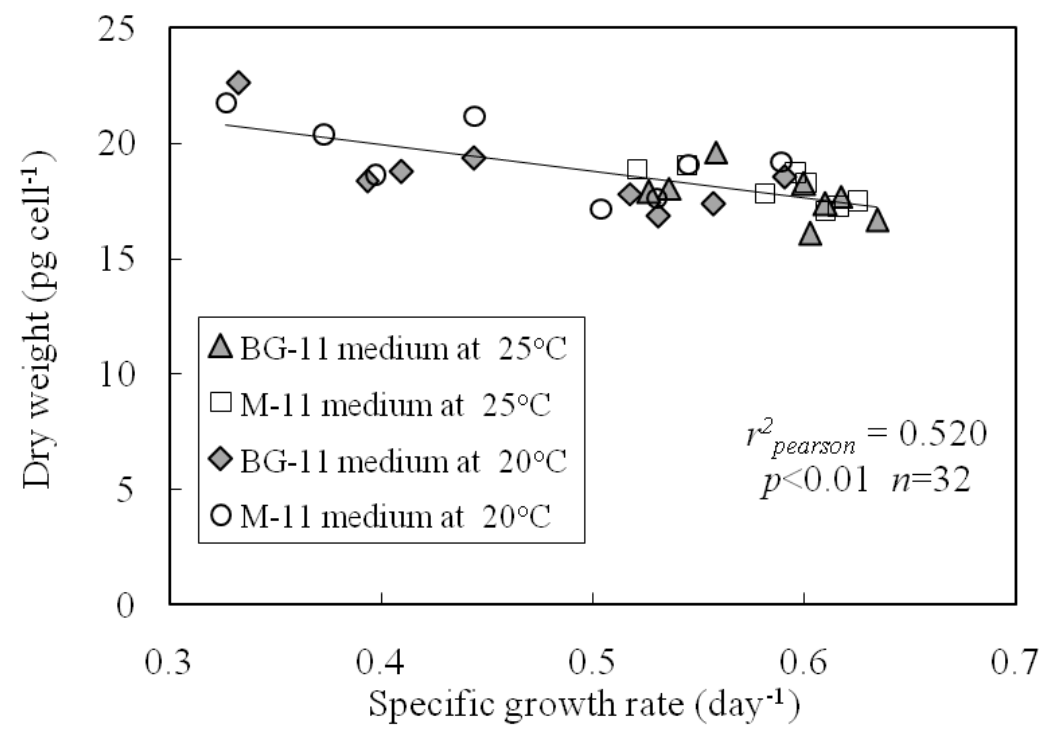

[Fig. 2] 

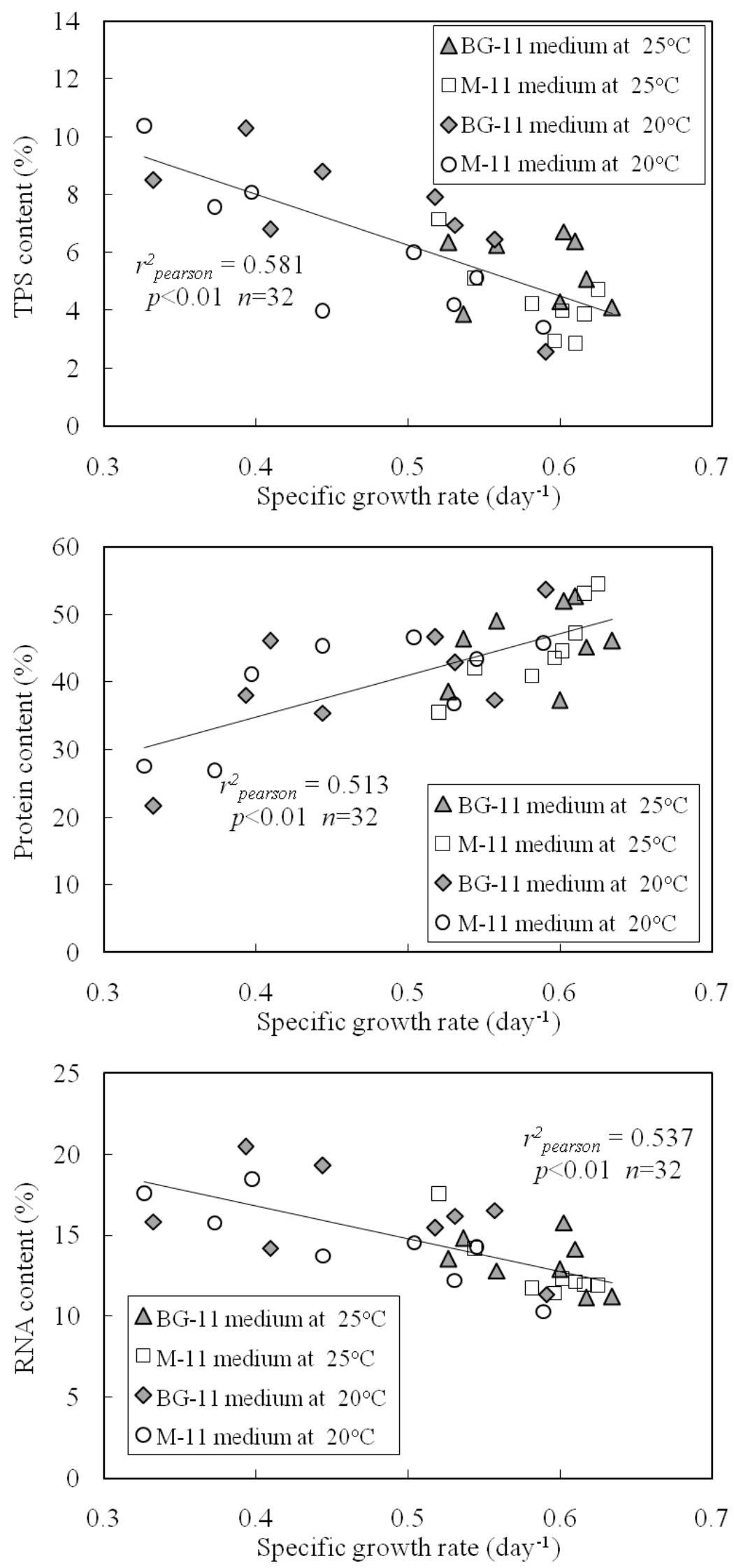

[Fig. 3] 

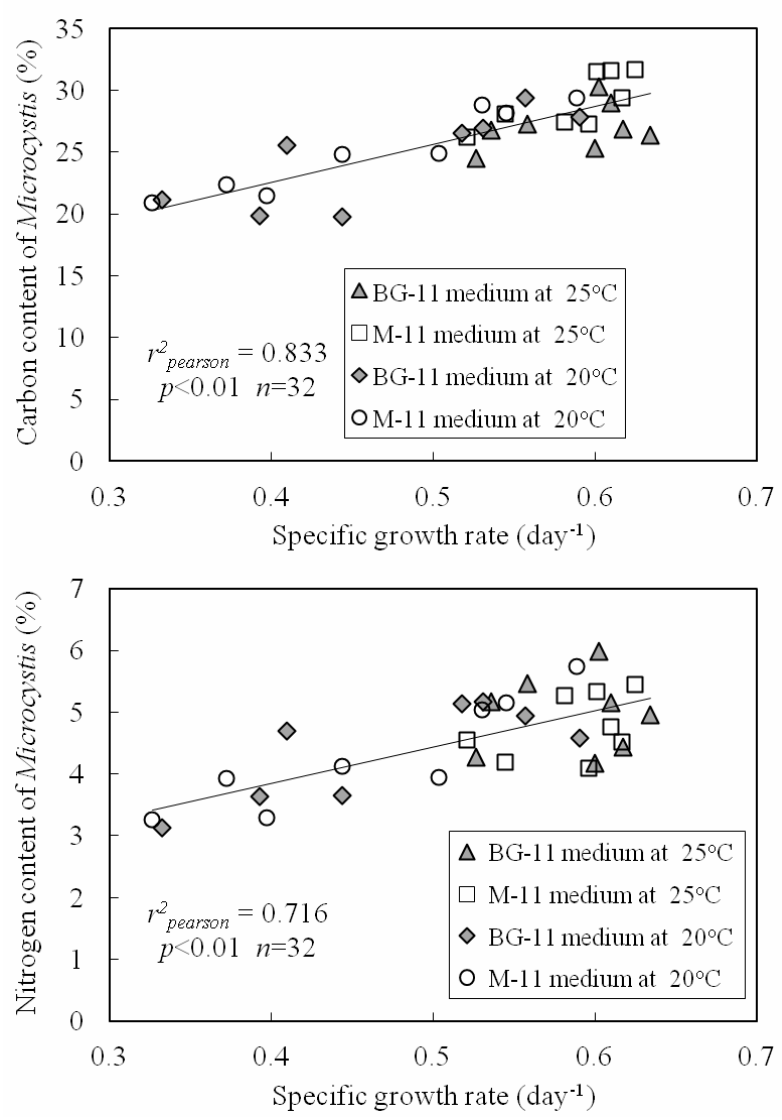

[Fig. 4]

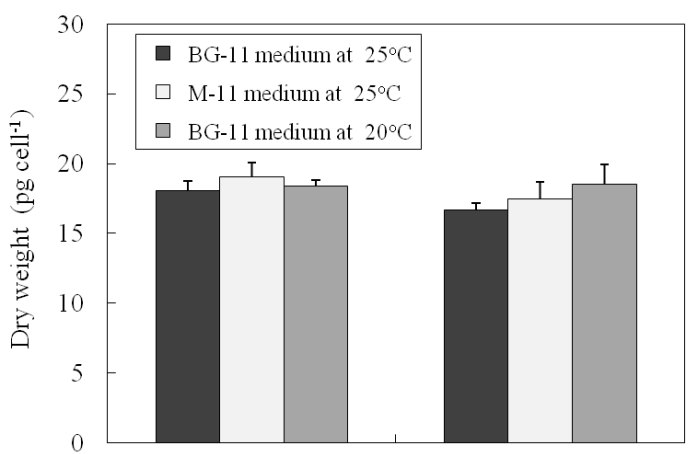

30

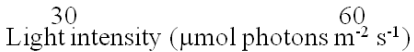

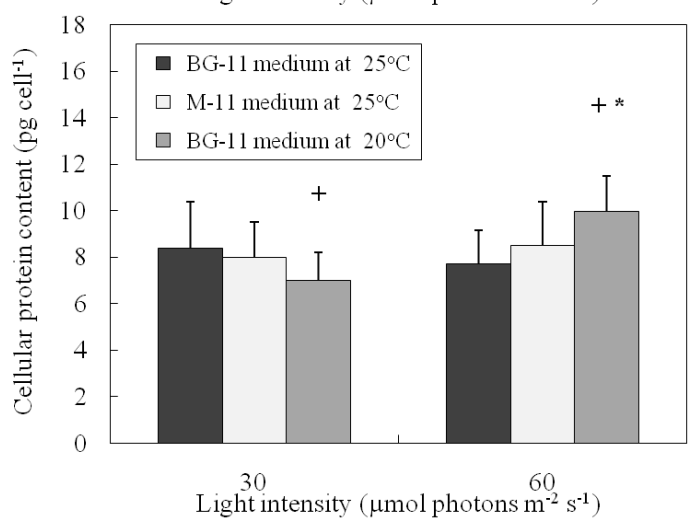

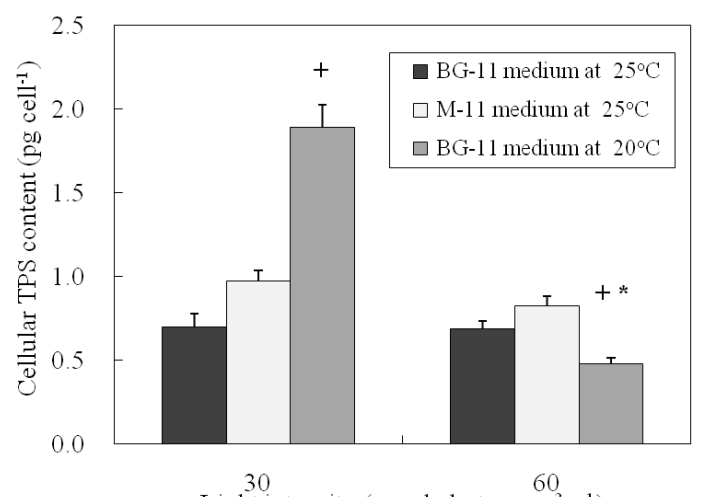

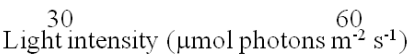

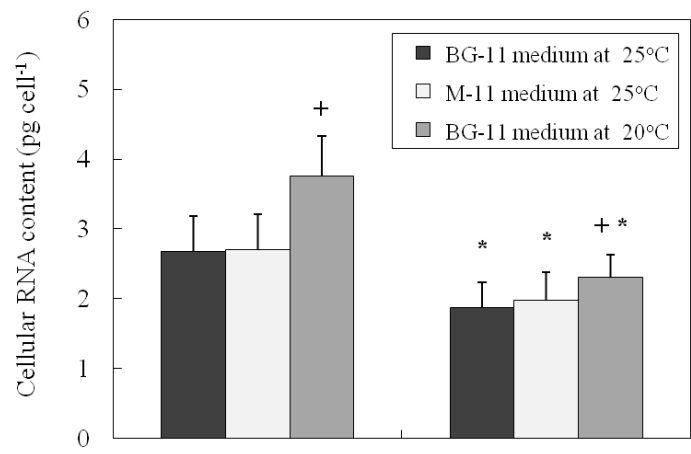

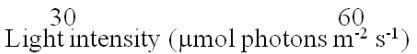

[Fig. 5] 